International Journal of Public Health Excellence (IJPHE)

Vol. 1, No. 1, January 2022, pp. 27 31

Journal homepage: https://ejournal.ipinternasional.com/index.php/ijphe/

ISSN: 2809-9826, DOI: https://doi.org/10.55299/ijphe.v1i1.7

\title{
The Relationship Compliance with Fe Tablet Consumption with Anemia in Pregnant Women
}

\author{
Rostina Afrida Pohan \\ ${ }^{1}$ Diploma 3 Midwifery Study Program, Sakinah Husada Tanjungbalai High School Of Health Sciences, Indonesia
}

\begin{tabular}{|c|c|}
\hline Article Info & ABSTRACT \\
\hline Article history: & \multirow{11}{*}{$\begin{array}{l}\text { Oral administration of iron is one approach for the prevention and control of } \\
\text { iron deficiency anemia. Supplementation should be given in the } 2 \text { nd and 3rd } \\
\text { trimesters, when the efficiency of absorption is increased and the risk of } \\
\text { nausea and vomiting is reduced. The Ministry of Health in Indonesia } \\
\text { recommends giving iron tablets to all pregnant women around } 60 \mathrm{mg} \text { per } \\
\text { day for } 90 \text { days. The purpose of this study was to determine the relationship } \\
\text { between adherence to consuming Fe tablets and the incidence of anemia in } \\
\text { pregnant women. This research uses correlation descriptive research method } \\
\text { with cross sectional design. The population in this study were all pregnant } \\
\text { women who visited the Sei Tualang Raso Public Health Center as many as } \\
35 \text { people using purposive sampling technique, data analysis was carried out } \\
\text { with the chi-square test. The results showed that there was a relationship } \\
\text { between adherence to consuming Fe tablets and the incidence of anemia in } \\
\text { pregnant women at the Sei Tualang Raso Health Center, Tanjungbalai City } \\
\text { in } 2021 \text {, this was evidenced by the results of the chi-square test with p-value } \\
=0.005 \text {. For mothers Pregnant women are expected to be more routinely } \\
\text { check their pregnancy and obediently consume iron tablets. }\end{array}$} \\
\hline Received November 23, 2021 & \\
\hline Revised December 12, 2021 & \\
\hline Accepted December 27, 2021 & \\
\hline Corresponding Author: & \\
\hline Rostina Afrida Pohan & \\
\hline Diploma 3 Midwifery Study & \\
\hline Program, Sakinah Husada & \\
\hline Tanjungbalai High School Of & \\
\hline Health Sciences, Indonesia & \\
\hline Email: pohanrose@gmail.com & \\
\hline
\end{tabular}

Keywords:

Compliance, Fe Tablets, Anemia

This article is licensed under a Creative Commons AttributionShareAlike 4.0 International License..

\section{INTRODUCTION}

Pregnancy is a period that really determines the quality of human resources in the future because the growth and development of children is very much determined from the time of the fetus in the womb. If the health condition and nutritional status of pregnant women are good, there is a great chance that the fetus they will contain will be good and the safety of the mother during childbirth will be guaranteed.

Anemia is a disease caused by a deficiency of hemoglobin $(\mathrm{Hb})$. A person is said to have severe anemia if he has a hemoglobin $(\mathrm{Hb})$ of less than $10 \mathrm{~g} \%$ [18]. The large increase in blood volume means that additional iron is needed to make hemoglobin for the increased red blood cells. The more hemoglobin contained in the blood, the more oxygen that can be carried to various tissues including the placenta.

Based on the Profile of the Medan City Health Office [5]-[6], an anemia survey conducted in 2005 in 4 districts / cities in North Sumatra, namely Medan City, Binjai, Deli Serdang Regency and Langkat, it was found that $40.50 \%$ of female workers suffered from anemia. One of the efforts made to reduce the prevalence of anemia is by giving 90 tablets of iron $(\mathrm{Fe})$ during pregnancy.

Anemia adversely affects pregnancy, more severe anemia, however, can increase the risk of anemia in the baby. In addition, if there is significant anemia during the first trimester, there is a greater risk of giving birth to premature babies or low birth weight babies. Anemia also increases the risk of blood loss during labor and makes it more difficult to fight infection.

From the preliminary survey that the researchers conducted at the Sei Tualang Raso Health Center in January 2021, there were 36 pregnant women who visited the Sei Tualang Raso Health Center and there were 8 people who experienced anemia from the results of the examination, and based on the results of interviews conducted at the Puskesmas on 10 There are only 4 pregnant women who consume one pack of Fe tablets within 30 days by consuming them regularly, while others say that sometimes they consume sometimes not so that one pack of Fe tablets has not been used up within 30 days and this is reinforced by the statement expressed by the officer. 
Health Center of Sei Tualang Raso Health Center that the distribution of Fe tablets to pregnant women has been carried out but the incidence of anemia in pregnant women still occurs. [19]-[20].

A concise and factual abstract is required. The abstract should state briefly the purpose of the research, the principal results and major conclusions. An abstract is often presented separately from the article, so it must be able to stand alone. For this reason, References should be avoided, but if essential, then cite the author(s) and year(s). Also, non-standard or uncommon abbreviations should be avoided, but if essential they must be defined at their first mention in the abstract itself. Immediately after the abstract, provide a maximum of 7 keywords, using American spelling and avoiding general and plural terms and multiple concepts (avoid, for example, 'and', 'of'). Be sparing with abbreviations: only abbreviations firmly established in the field may be eligible. These keywords will be used for indexing purposes. Based on this background, the authors are interested in conducting research with the title Relationship of Compliance with Fe Tablets with the Incidence of Anemia in Pregnant Women at the Sei Tualang Raso Health Center, Tanjungbalai City in 2021. [10]-[12].

Iron $(\mathrm{Fe})$ is an essential micro element for the body that is needed in the synthesis of hemoglobin. Consumption of iron tablets is closely related to hemoglobin levels in pregnant women. Iron deficiency anemia that is often experienced by pregnant women is caused by adherence to consuming iron tablets that are not good or the wrong way of consuming it, causing a lack of iron absorption in the mother's body. According to Prasetyono [21], there are several functions of iron tablets, namely iron serves to maintain pregnancy. Pregnant women who lack iron can interfere with the delivery process and bleeding can occur after delivery. According to Angreni [1]-[2], the amount of iron in a person's body ranges from 3-5 grams depending on gender, weight and hemoglobin. Iron in the body is found in hemoglobin as much as $1.5-3.0 \mathrm{~g}$ and the rest is found in plasma and tissues. In the plasma iron is bound to a protein called "transferrin" which is as much as 3-4 grams. While in the network is in an essential and not essential status. Called essential because it can not be used for the formation of $\mathrm{Hb}$ or other purposes. Iron requirements in singleton pregnancies are 200-600 mg to meet red blood cell mass, 200-370 mg for fetuses depending on birth weight, 150-200 mg for external losses, 30-170 mg for umbilical cord and placenta, 90-310 mg to replace blood lost during delivery. The total need for iron in pregnancy ranges from 580-1,340 mg and 440-1,050 $\mathrm{mg}$ of which will be lost in the mother's body during childbirth.

The concept of Compliance is the degree of appropriateness of an individual's behavior with medical or health advice. By describing the use of drugs according to the instructions on the prescription and including their use at the right time.

Anemia in pregnancy is a maternal condition with hemoglobin levels below $11 \mathrm{~g} \%$ in the first and third trimesters, or hemoglobin levels $<0.5 \mathrm{~g} \%$ in the first and second trimesters [5]-[6]. Anemia is a condition in which red blood cells decrease in hemoglobin, so that the oxygen-carrying capacity for the needs of vital organs in the mother and fetus is reduced during pregnancy, an indication of anemia is if the hemoglobin concentration is less than $10.5 \mathrm{~g} \%$ to $11 \mathrm{~g} \%$.

\section{METHOD}

The design used in this study is descriptive correlation with a cross sectional approach which aims to find out how big the relationship between pregnant women's compliance in consuming iron tablets with the incidence of anemia at the Sei Tualang Raso Public Health Center, Tanjungbalai City. Population is a generalization area consisting of subjects that have certain quantities and characteristics to be studied and drawn conclusions. The population in this study were all pregnant women who visited the Sei Tualang Raso Health Center, Tanjungbalai City. The sample is part of the population with the same characteristics as the population. The sampling technique in this research is purposive sampling, namely the researcher determines the sample himself to be taken because there are certain considerations. Inclusion criteria are general characteristics of research subjects from an affordable target population to be studied [15][17]. The inclusion criteria in this study were: 1). Pregnant women who check their pregnancies at the Sei Tualang Raso Health Center. 2). Pregnant women who are willing to be respondents. 3). Pregnant women who get Fe tablets for 1 month. Research instruments are tools that will be used for data collection. Collecting data used in this study for the variable compliance of mothers taking Fe tablets using a questionnaire taken from Nirdayani's research entitled The Effect of Compliance with consuming Fe tablets on Hemoglobin $(\mathrm{Hb})$ levels in the work area of the Central Aceh City Health Center as many as 12 questions.

The research was conducted after the researcher received approval from the educational institution, namely the Public Health Sciences Study Program STIKes Sakinah Tanjungbalai and permission from the Head of the Sei Tualang Raso Health Center. There are several matters relating to ethical issues, namely providing explanations to prospective research respondents about the objectives, benefits and procedures of conducting research. The researcher will make a research approval letter (informed consent), which is an agreement to become a respondent, and be signed by the respondent.

After the respondent signed the consent form, then the researcher gave a questionnaire to be filled out by the respondent. After the respondents filled out the questionnaire, then the researcher gave a statement table to the respondents to fill in. 
Table 1. Operational Definition

\begin{tabular}{|c|c|c|c|c|c|}
\hline No & Variable & Operational Definition & Scale & $\begin{array}{l}\text { Measuring } \\
\text { instrument }\end{array}$ & Result Category \\
\hline 1 & $\begin{array}{l}\text { Independent variable of } \\
\text { adherence to consume Fe } \\
\text { tablets }\end{array}$ & $\begin{array}{l}\text { Compliance of pregnant } \\
\text { women in consuming iron } \\
\text { tablets as seen from the } \\
\text { accuracy of the number of } \\
\text { iron tablets consumed by } \\
\text { pregnant women and the } \\
\text { frequency of consuming } \\
\text { iron every day }\end{array}$ & Nominal & Questionnaire & $\begin{array}{ll}\text { a. } & \text { Obey } \\
\text { b. } & \text { Not obey }\end{array}$ \\
\hline 2 & $\begin{array}{l}\text { Dependent Variable } \\
\text { Incidence of Anemia }\end{array}$ & $\begin{array}{l}\text { The level of hemoglobin in } \\
\text { the blood of pregnant } \\
\text { women less than normal } \\
(\mathrm{Hb}<11 \mathrm{~g} \% \text { ) at the time } \\
\text { of ANC visit at the } \\
\text { Puskesmas }\end{array}$ & Ordinal & Hemometer Sahli & $\begin{array}{ll}\text { a. No Anemia, } \\
\text { if } \mathrm{Hb} 11 \mathrm{~g} \% \\
\text { b. Anemia, if } \\
\mathrm{Hb}<11 \mathrm{~g} \%\end{array}$ \\
\hline
\end{tabular}

In conducting the analysis, especially on research data, applied statistics will be used which is adapted to the purpose to be analyzed [8]. The analysis can be carried out in stages including:

a. Univariate Analysis

This analysis was conducted to obtain an overview of each independent variable and dependent variable. The data is presented in the form of a frequency distribution table.

b. Bivariate Analysis

This analysis aims to determine the relationship between the independent variable (adherence to pregnant women taking Fe tablets) and the dependent variable (the incidence of anemia). To prove whether there is a relationship, a Chi-Square test statistic was performed with a $95 \%$ confidence degree $(\alpha=0.05)$. If the $p$ value $<0.05$, it indicates that there is a significant relationship between the independent variable and the dependent variable.

\section{RESULTS AND DISCUSSION}

In this section, the results of research will be presented regarding the relationship between adherence to consuming Fe tablets and the incidence of anemia in pregnant women at the Sei Tualang Raso Health Center, Tanjungbalai City in 2021.

\subsection{Results}

Table 2

The relationship between adherence to taking Fe tablets and the incidence of anemia in pregnant women at the Sei Tualang Raso Public Health Center, Kota Tanjungbalai Year 2021

\begin{tabular}{|c|c|c|c|c|c|c|c|}
\hline \multirow{3}{*}{$\begin{array}{l}\text { Compliance with taking Fe } \\
\text { tablets }\end{array}$} & \multicolumn{4}{|c|}{ Anemia } & \multirow{2}{*}{\multicolumn{2}{|c|}{ Total }} & \multirow{3}{*}{$\mathrm{P}$} \\
\hline & \multicolumn{2}{|c|}{ Anemia } & \multicolumn{2}{|c|}{ Tidak Anemia } & & & \\
\hline & Amount & Percent & Amount & Percent & Amount & Percent & \\
\hline Obey & 0 & 0 & 12 & 34,3 & 12 & 34,3 & \\
\hline Not obey & 11 & 31,4 & 12 & 34,3 & 23 & 65,7 & 0.005 \\
\hline Total & 11 & 31,4 & 44 & 68,6 & 35 & 100 & \\
\hline
\end{tabular}

Based on table 2, it is known that from 35 respondents the majority of 23 respondents who did not comply with consuming Fe tablets experienced anemia as many as 12 (34.3\%), while the 12 respondents who complied with consuming Fe tablets, as many as $12(34.3 \%)$ all did not experience anemia. . The results of the statistical test obtained a $\mathrm{p}$ value $=0.005$, it can be concluded that there is a relationship between adherence to consuming Fe tablets and the incidence of anemia in pregnant women at the Sei Tualang Raso Health Center, Tanjungbalai City in 2021.

\subsection{Discussion}

\subsubsection{Characteristics of respondents}

Based on the results of research conducted at the Sei Tualang Raso Health Center, Tanjungbalai City, the majority of 35 respondents were in the age range of 21-35 years as many as $31(88.6 \%)$. A healthy reproductive age for pregnant women is between 20-35 years and age is influential in carrying out an action, because one's memory power is influenced by age. The older a person is, the function of his organs also decreases, including memory. The lower the function of the body's organs and memory, the lower a person's activity in carrying out an action [2]-[3] . According to the Indonesian Ministry of Health [8], the age group at risk is < 20 years or > 35 years. Maternal age at birth of less than 20 years or more than 35 years has been proven to be a high cause of morbidity and even mortality for both mother and child.

In terms of education, the majority of respondents graduated from junior high school as many as 15 (42.9\%). According to [24], the higher a person's education level, the easier it is to receive information from other people and from the mass media, so that the more knowledge they have, they will think ahead and are eager to try Int Jou of PHE 
new things or ways. With these properties, they push them out of the environment and into a wider social circle. Education has a huge influence on a person's knowledge, the higher a person's education, the easier it is for that person to receive information, the more information that enters the more knowledge that person has. Education is influential in taking action, because the higher the level of education, the higher the knowledge, meaning that the guidance given to pregnant women about the correct technique of consuming iron tablets can be more easily understood [22].

In terms of parity, the majority of multigravida respondents were $15(35 \%)$. Parity of more than 3 is a factor in the occurrence of anemia. This is because being pregnant too often can deplete the mother's body of nutrient reserves [2].

\subsubsection{Compliance with taking Fe tablets}

Based on the results of research conducted at the Pijorkoling Public Health Center, Padangsidimpuan, the majority of 35 respondents did not comply with consuming Fe tablets as much as 23 (65.7\%). According to Siregar (2006), compliance is the level of appropriateness of an individual's behavior with medical or health advice. By describing the use of drugs according to the instructions on the prescription and including their use at the correct time. Anemia in pregnancy generally occurs due to lack of iron in the body. During pregnancy iron absorption is more efficient and responds very well to oral ferrosulfate treatment. Thus anemia in pregnant women can be prevented and treated by giving ferrosulfate pills every day, thus it is hoped that with a high level of compliance it can reduce the incidence of anemia in pregnant women.

\subsubsection{Anemia}

Based on the results of research conducted at the Sei Tualang Raso Health Center, Tanjungbalai City, 24 $(68.6 \%)$ of 35 respondents had anemia. Usually, non-pregnant women have a normal hemoglobin of 12-15gr\%. And pregnant women also usually have a hemoglobin of 12-15 gr \%. However, pregnant women have a greater risk of suffering from anemia. Usually the condition of pregnant women who are anemic are those who have $\mathrm{Hb}<11 \mathrm{~g} \%$ in the first and third trimesters or Hb levels $<10.5 \mathrm{~g} \%$ in the second trimester. Because there is a difference with the condition of non-pregnant women because hemodilution mainly occurs in the second trimester [18].

\subsubsection{The relationship between adherence to consuming Fe tablets with the incidence of anemia}

Based on the results of research conducted at the Sei Tualang Raso Health Center, Tanjungbalai City, it is known that of the 35 respondents the majority of 23 respondents who did not comply with consuming Fe tablets experienced anemia as many as $12(34.3 \%)$, while the 12 respondents who obediently consumed Fe tablets were as many as $12(34.3 \%)$ all did not have anemia.

According to the researcher, pregnant women who are obedient in consuming Fe tablets, namely pregnant women who consume $\mathrm{Fe}$ tablets with the right dose and the right way of drinking will not experience anemia compared to respondents who do not comply with taking iron tablets.

The results of the analysis of the relationship between adherence to consuming Fe tablets and the incidence of anemia in pregnant women at the Sei Tualang Raso Health Center, Tanjungbalai City in 2021, obtained a p value $=0.005$, it can be concluded that there is a relationship between adherence to consuming Fe tablets and the incidence of anemia in pregnant women at the Sei Tualang Raso Health Center Tanjungbalai City. In 2021, from these results it can be concluded that $\mathrm{p}$ value $<0.005$ so $\mathrm{H} 0$ is rejected and $\mathrm{Ha}$ is accepted, meaning that there is a significant relationship between adherence to consuming Fe tablets and the incidence of anemia in pregnant women at the Sei Tualang Raso Health Center, Tanjungbalai City in 2021.

From this research, the researchers concluded that the higher the level of compliance of pregnant women in consuming Fe tablets during pregnancy, the incidence of anemia will also be smaller. So it needs to be maintained and improved again by conducting continuous counseling and consultation to pregnant women who check their pregnancy so that pregnant women understand more about the importance of consuming Fe tablets during pregnancy and also pregnant women are more effective in consuming the Fe tablets.

\section{CONCLUSION}

After conducting research on the relationship between adherence to consuming Fe tablets and the incidence of anemia in pregnant women at the Sei Tualang Raso Health Center, Tanjungbalai City in 2021, the following conclusions can be drawn:

1. Based on the characteristics of the respondents, the majority were in the age range of 21-35 years as many as $31(88.6 \%)$ and based on the latest education the majority graduated from junior high school as many as 15 $(42.9 \%)$ while based on parity the majority were multigravida as many as 15 (35\%).

2. Based on compliance in consuming Fe tablets, the majority did not comply with consuming Fe tablets as much as $23(65,7 \%)$.

3. Based on the incidence of anemia, the majority of respondents experienced anemia as many as $24(68.6 \%)$. 
4. There is a relationship between adherence to consuming Fe tablets with the incidence of anemia in pregnant women at the Sei Tualang Raso Health Center, Tanjungbalai City in 2021, this is evidenced by the results of the chi-square test with $\mathrm{p}$-value $=0.005$

\section{ACKNOWLEDGEMENTS}

Author thanks to Head of Sakinah Tanjungbali School of Health Sciences and Head of Sei Tualang Raso Health Center. In most cases, sponsor and financial support until the completion of this research.

\section{REFERENCES}

[1] Angreini "Compliance of Pregnant Women in Consuming Iron Tablets", Scientific Papers,.Stikes Yarsis, Surabaya, 2008

[2] Arisman, M.B, Textbook of Nutrition in the Life Cycle, Vol. 4, $2^{\text {nd }}$ ed, EGC, Jakarta, Indonesia, 2008.

[3] Arisman, M.B, Textbook of Nutrition in the Life Cycle, Vol. 5, $2^{\text {nd }}$ ed, EGC, Jakarta, Indonesia, 2008.

[4] Ahyar, "Epidemiology of Anemia in Pregnant Women, 12 January 2020, [Online], http://www.Ahyar.web.id/2010/10/Epidemilogi-pada ibu-hamil.

[5] Dinkes Propsu. " Health Profile of North Sumatra Province " [2010], Provinsi Sumatera Utara.

[6] Depkes RI, "Operational Guidelines for the Management of Nutritional Anemia in Indonesia". [2008], Jakarta.

[7] Evawany, " The Relationship between Nutritional Status and the Incidence of Anemia in First Trimester Pregnant Women at BPS Sri Hastuti Surabaya", Scientific Papers: Stikes Yarsis, Surabaya, 2010.

[8] Hidayat, A. Midwifery Research Methods Data Analysis Techniques. Fourth Printing, Vol. 2, 3rd ed, Salemba Medika, Jakarta, 2010.

[9] James, Robert, Jerome, Public Health An Introduction, Vol. 1, $4^{\text {th }}$ ed, EGC, Jakarta, Indonesia, 2007.

[10] Indonesian Ministry of Health, "Indonesia Health Profile 2010". [2011], Jakarta.

[11] Indonesian Ministry of Health, Riskesdas results related to maternal health. 18 Januari 2020, [Online], http://www.kesehatanvu.depkes.go.id/archives/689

[12] Indonesian Ministry of Health, "Indonesia Health Profile 2014", 16 Januari 2020, [Online], http://www.depkes.go.id,Jakarta

[13] Mayo, Healthy Pregnancy Clinic, Vol. 1, $1^{\text {st }}$ ed, MITRA MEDIA, Jakarta, Indonesia, 2011.

[14] Mawadah, Hardiansyah. Healthy Diet and Lifestyle, Vol. 3, $3^{\text {rd }}$ ed, Nurhamedika, Yogyakarta, 2008.

[15] Nirdayani, "The effect of adherence to consuming Fe tablets on hb levels in the work area of the Central Aceh Health Center", Research Paper, FKM USU, Medan, 2012.

[16] Notoadmodjo, S., Health Education and Behavior. Vol. 2, 2 $2^{\text {nd }}$ ed, Rineka Cipta, Jakarta, Indonesia, 2007.

[17] Notoadmodjo, S., Health Education and Behavior. Vol. 1, $3^{\text {rd }}$ ed, Rineka Cipta, Jakarta, Indonesia, 2010.

[18] Proverawati, A., Anemia and Pregnancy Anemia, Vol. 3, No. $4^{\text {th }}$ ed, Nuha Medik, Yogyakarta, Indonesia, 2012.

[19] Indonesian Health Profile, "Ministry of Health Republic of Indonesia 2008", 4 December 2012 [Online], http://www.depkes.go.id

[20] Health Profile of North Sumatra Province, North Sumatra Provincial Health Office. FE Tablet Consumption Compliance Attitude. Vol. 1, $2^{\text {nd }}$ ed, ESA UNGGUL, Jakarta, 2008.

[21] Prasetyono, Nutritional Needs of Pregnant Women. Vol 2, $2^{\text {nd }}$ ed, IPB Press. Bogor, 2009.

[22] Yenni, M., Comparison of Effects of TTD Supplementation With and Without Vitamin C on Hb Levels of Female Workers in Playwood Companies, Vol. 1, $2^{\text {nd }}$ ed, Jo Press, Jakarta, 2007.

[23] Almarita and Fallah, "The Effect of Chronic Energy Deficiency (KEK) Risk on Pregnant Women on Low Baby Weight". Theses. Medan: University of Northern Sumatra, 2000

[24] Yuliastuti Erni. "Factors Associated with Chronic Energy Deficiency in Pregnant Women in the Work Area of Sungai Bilu Health Center Banjarmasin", Theses, Banjarmasin, 2014.

[25] Hasaini, Nanang, " Husband's Support Reassures Mother-to-be", 18 Maret 2020, [Online] http://www.tabloidnova.com/ Nova/Keluarga/Pasangan/DukunganSuamiMenenteramkan Calon Ibu>. 